\title{
Height and number of shoots on the survival and development of micropropagated bamboo plantlets during pre-acclimatization ${ }^{1}$
}

\author{
Paulo Arthur Almeida do Vale ${ }^{2}$, João Bosco de Oliveira Júnior ${ }^{3}$, \\ Frederico Henrique da Silva Costa ${ }^{3}$, Jonny Everson Scherwinski-Pereira ${ }^{4}$
}

\section{ABSTRACT}

During the in vitro multiplication of bamboo plantlets, it is common the formation of shoots aggregates. Once individualized, these can yield a greater number of plantlets than if planted in clusters. This study aimed to evaluate the effect of the relationship between height and number of initial shoots in micropropagated bamboo plantlets on the survival and development of plants, during the pre-acclimatization stage. Guadua aff. chaparensis shoots, after successive subcultures of in vitro multiplication, were classified into three height classes $(2.5-5.0 \mathrm{~cm} ; 5.1-10.0 \mathrm{~cm} ; 10.1-15.0 \mathrm{~cm})$ and number of aggregate shoots (one shoot per plantlet/single-stem plantlet, two and three shoots per plantlet) and pre-acclimatized in a commercial substrate composition plus washed sand. The plantlets were evaluated for survival, height, number of new shoots and roots, shoot and root fresh and dry mass. In plantlets from micropropagation, the plant height does not influence the survival rates, being acclimatized preferably at heights between $5.0 \mathrm{~cm}$ and $15.0 \mathrm{~cm}$, with survival rates of up to $97 \%$. Plantlets with height starting at $5.1 \mathrm{~cm}$ and composed of 2 or 3 initial shoots show a greater vigor and ex vitro growth, a fact evidenced by the higher values obtained in relation to height and emission of new shoots and roots, as well as a greater fresh and dry biomass accumulation.

KEYWORDS: Guadua aff. chaparensis, Bambusoideae, vegetative propagation.

\section{INTRODUCTION}

Brazil has a favorable climate and vast territory, including degraded areas considered unsuitable for agriculture, but suitable for the planting of bamboo species of commercial value, which could make the nation a major producer and

\section{RESUMO}

Altura e número de brotos na sobrevivência e desenvolvimento de mudas micropropagadas de bambu durante a pré-aclimatização

Durante a multiplicação in vitro de bambu, é rotineiro ocorrer a formação de agregados de brotos. Uma vez individualizados, eles podem render maior número de mudas do que se plantados agrupados. Objetivou-se avaliar o efeito da relação entre a altura e o número de brotos iniciais em mudas de bambu micropropagadas na sobrevivência e desenvolvimento das plantas, durante a préaclimatização. Brotações de Guadua aff. chaparensis, após sucessivos subcultivos de multiplicação in vitro, foram classificadas em três classes de altura $(2,5-5,0 \mathrm{~cm} ; 5,1-10.0 \mathrm{~cm} ; 10,1-15,0 \mathrm{~cm})$ e número de brotos agregados (um broto por planta/muda com haste única, dois e três brotos por muda) e pré-aclimatizadas em composição de substrato comercial e areia lavada. Foram avaliados a sobrevivência, altura, número de novos brotos e raízes, massa fresca e seca da parte aérea e raízes. Em mudas provenientes de micropropagação, a altura das plantas não influencia nas taxas de sobrevivência, podendo ser aclimatizadas, preferencialmente, com alturas entre $5,0 \mathrm{~cm}$ e 15,0 cm, com taxas de sobrevivência de até $97 \%$. Mudas com altura superior a $5,1 \mathrm{~cm}$ e compostas por 2 ou 3 brotos iniciais apresentam maior vigor e crescimento ex vitro, fato comprovado pelos maiores valores obtidos em relação à altura e emissão de novos brotos e raízes, bem como maior acúmulo de biomassa fresca e seca.

PALAVRAS-CHAVE: Guadua aff. chaparensis, Bambusoideae, propagação vegetativa.

worldwide exporter of this raw material. Therefore, it is essential to advance research and development programs with technologies capable of generating a scientific knowledge that ensures technological innovation, sustainability and potentialization of the use of native and planted bamboo, which represent an innovative and interesting alternative to the Brazilian

1. Received: Jun. 30, 2018. Accepted: Sep. 27, 2018. Published: Mar. 11, 2019. DOI: 10.1590/1983-40632019v4953751.

2. Fundação de Tecnologia do Estado do Acre, Laboratório de Sementes e Micropropagação, Rio Branco, AC, Brasil. E-mail/ORCID: arthurvale@bol.com.br/0000-0001-6197-8983.

3. Universidade Federal do Acre, Laboratório de Biotecnologia e Anatomia Vegetal, Rio Branco, AC, Brasil.

E-mail/ORCID: junior.jboj@gmail.com/0000-0002-9936-145X, fredericohenrique@yahoo.com.br/0000-0003-0118-3438.

4. Empresa Brasileira de Pesquisa Agropecuária (Embrapa Recursos Genéticos e Biotecnologia), Brasília, DF, Brasil. E-mail/ORCID: jonny.pereira@embrapa.br/0000-0001-6271-332X. 
agribusiness (Kleinhenz \& Midmore 2001, Das et al. 2008, Greco et al. 2011).

However, despite the versatility of uses and the potential of bamboo as a raw material, an important limitation for the development of the production chain of this plant refers to the slow and deficient vegetative multiplication process. Additionally, the bamboo flowering, which is generally a rare phenomenon and, depending on the species, may occur after decades (Ramanayake 2006, Lin et al. 2010, Zhao et al. 2015) and exhibit a low seed viability, hinders its sexual propagation.

For this reason, bamboo plants are propagated vegetatively, primarily by techniques such as direct transplanting (clump unfolding) and rooting cuttings (culm fragments) (Sousa 2018), which, although relatively efficient, are neither economically feasible nor recommended for the large-scale production of plantlets (Singh et al. 2013, Nogueira et al. 2017).

Thus, due to the inconvenience and limitations associated with sexual and asexual reproduction methods, micropropagation is an excellent alternative for the clonal multiplication of bamboo in a continuous way and with phytosanitary certification. After developing the protocol to the species, this technique allows a large-scale plant production and ensures genetic identity, starting from somatic tissue from selected matrices of high agronomic and commercial value, where other propagation processes are less advantageous (Gillis et al. 2007, Nogueira et al. 2017, Gantait et al. 2018).

Of all the micropropagation stages, acclimatization is one of the most important, because it is the last phase in which plants need to be gradually adapted to the ex vitro environment. For many species, this stage is determinant for the success of the commercial production of micropropagated plantlets, since, in the laboratory, they are under an environment with high relative humidity, reduced light intensity, limited gas exchange and constant temperature and photoperiod, conditions very different from when transplanted to the natural environment. Accordingly, plants developed in vitro become heterotrophic and may exhibit limited structural and functional characteristics and, when subjected to acclimatization, are exposed to moderate or severe environmental stress (Van Huylenbroeck \& Debergh 1996, Luis et al. 2010, Mishra et al. 2011, Singh et al. 2013, Gomes et al. 2015). Moreover, for bamboo, there is also the heterogeneous size of the plants and the number of clusters aggregated to the plantlets when they are taken to acclimatization, which may interfere in the transpiration, energy metabolism, vigor and emission of new shoots during the ex vitro stage, characteristics that may quickly lead to the plant death under greenhouse conditions.

Due to the low volume of information on the factors that influence the acclimatization of micropropagated bamboo plantlets, this study aimed to evaluate the effect of the relationship between height and number of initial shoots in micropropagated bamboo plantlets (Guadua aff. chaparensis) on the survival and development of plants, during the pre-acclimatization stage.

\section{MATERIAL AND METHODS}

The in vitro culture was carried out at the Fundação de Tecnologia do Estado do Acre and the experiment conducted at the Universidade Federal do Acre, both in Rio Branco, Acre state, Brazil, from May to August 2016. Guadua aff. chaparensis material was used. A voucher specimen of the material is deposited in the herbarium of the Universidade de Brasília (voucher HPMU-321), in Brasília, Brazil.

The plantlets used in the experiment were obtained from in vitro seed germination, followed by successive subcultures of in vitro multiplication by separation of shoots and transferring to a fresh culture medium (Figure 1A). For micropropagation, the Murashige \& Skoog (1962) medium supplemented with $20 \mathrm{~g} \mathrm{~L}^{-1}$ of sucrose and $3.0 \mathrm{mg} \mathrm{L}^{-1}$ of $\mathrm{N}^{6}$ benzylaminopurine (BAP) was used, and $\mathrm{pH}$ was adjusted to $5.6 \pm 0.1$. Cultivation was carried out in the stationary liquid system, in $500 \mathrm{~mL}$ glass flasks with $80 \mathrm{~mL}$ of medium (Figure 1B). The cultures were kept in a growth chamber, with photoperiod of $16 \mathrm{~h}$, light intensity of $30 \mu \mathrm{mol} \mathrm{m} \mathrm{m}^{-2} \mathrm{~s}^{-1}$ (supplied by white tubular fluorescent lamps) and room temperature of $25 \pm 2{ }^{\circ} \mathrm{C}$.

Once obtained, the plantlets were transferred to liquid Murashige \& Skoog culture medium devoided of BAP and kept in a growth chamber for two months. The plants were then removed from the flasks, washed in tap water to remove the culture medium excess and pruned at the roots (average of $1.0 \mathrm{~cm}$ in length). Subsequently, the plants were classified according to the height and number of aggregate shoots (clusters). 


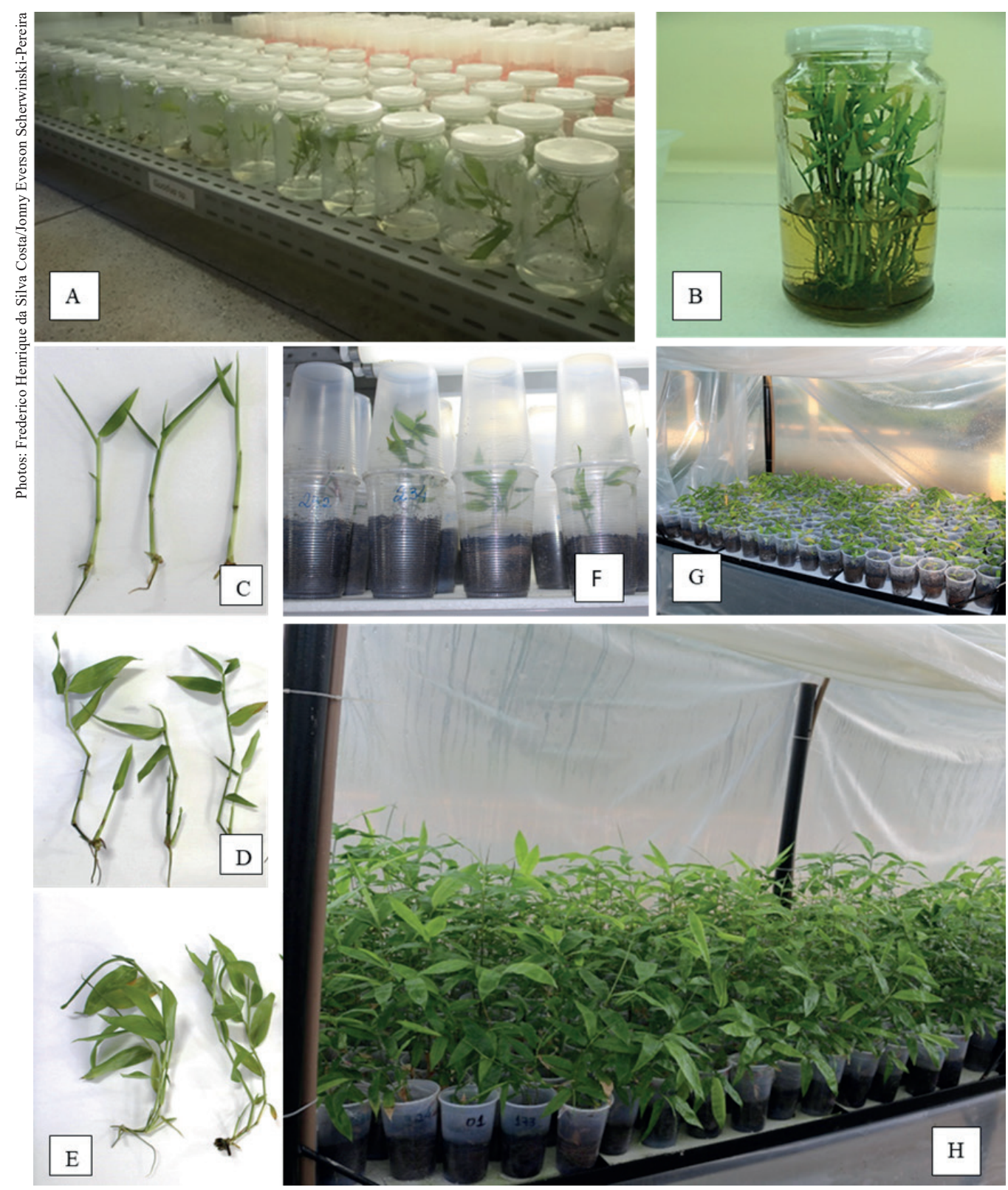

Figure 1. Aspects of the micropropagation and pre-acclimatization phases of Guadua aff. chaparensis bamboo plantlets: A) initial shoots under in vitro multiplication in Murashige \& Skoog (MS) medium with $3 \mathrm{mg} \mathrm{L}^{-1}$ of $\mathrm{N}^{6}$-benzylaminopurine; B) initial shoots in MS medium devoided of growth regulator; C-E) micropropagated and sorted plantlets, in relation to the number of shoots per plantlet; F) plantlets conditioned in a humid chamber system and kept in a growth chamber; G) plantlets at 30 days under greenhouse conditions; H) plantlets at 60 days under greenhouse conditions.

The experiment was conducted in a completely randomized design, in the pre-acclimatization phase. Treatments, in a $3 \times 3$ factorial arrangement, were represented by three classes of shoot height (CL1: 2.5-5.0 cm; CL2: 5.1-10.0 cm; CL3: 10.1-15.0 cm) and number of shoots per plantlet (CLns1: one shoot per plantlet/single-stem plantlet; CLns2: two shoots per plantlet; CLns3: three shoots per plantlet)
(Figures 1C-E). Twenty replicates per treatment were used, and the experimental unit consisted of a container with one plantlet or cluster.

Concurrently with classification, the plants were transferred to transparent polyethylene cups (500 $\mathrm{mL}$ capacity) previously perforated, containing a commercial substrate composition (Tropstrato-HT) and washed sand at a ratio of 2:1 (v/v) (Figure $1 \mathrm{~F})$. 
The pre-acclimatization protocol consisted of a period in a growth chamber with the same conditions mentioned previously, in a humid chamber cultivation system, for 30 days, followed by transferring to a greenhouse covered with plastic film and $70 \%$ of shading, where they were maintained for additional 60 days (Figures $1 \mathrm{G}-\mathrm{H}$ ). The plants were manually watered on a daily basis, with the aid of a sprayer.

Survival, plant height (measured with a ruler, from the plant base to the insertion of the last expanded leaf) and number of new shoots were evaluated monthly, for a period of up to 90 days. Survival was counted from the total number of plants per treatment (20 experimental units). At the end of this period, the root and shoot fresh and dry mass were determined. The dry mass was obtained at $65^{\circ} \mathrm{C}$, for $72 \mathrm{~h}$, in a forced circulation oven, until a constant value was verified.

In order to choose the most appropriate model for representing and applying the tests for statistical evaluation of the data, the $\mathrm{R}$ software environment was used, where the GLM models were applied using the Akaike information criterion, aided by the likelihood ratio test, to find relationships between possible model pairs.

For continuous variables of the "count" type, which assume non-negative integer values, the tested model considered $\mathrm{Y}$ as a variable with Poisson distribution. In the case of a binary response variable, the technique applied was that of generalized linear models. In the case of continuous variables responses, the criterion of discarding candidate models was used
(Burnham \& Anderson 2002). After this procedure, the analysis of variance (Anova) was used to verify the homoscedasticity (or heteroscedasticity) of the data through the residue graph and by the QQ plot. The averages were submitted to the residue normality (Shapiro-Wilk) and homogeneity (Bartlett 1937) tests. Data from the variables that did not meet one or both of the assumptions were transformed for residue normalization and/or homogenization of the variances. The averages were compared by the Tukey test at $5 \%$ of probability.

\section{RESULTS AND DISCUSSION}

For plant survival, the only significant likelihood ratio test was the Test 1 , which considers the comparison of the $\mathrm{Y} \sim 1$ model, without predictor variables, with the $\mathrm{Y} \sim \mathrm{B}$ model, that considers the number of initial shoots per plant. In the other tests, the inclusion in the $\mathrm{T}$ variable model (height class) did not show an evidence that it is a predictor of the survival condition of the plants, suggesting that, at 60 days, survival is not explained by the initial height of the micropropagated plant. Thus, the model chosen to represent survival at 60 days was $\mathrm{Y} \sim \mathrm{B}$ (Table 1).

Regarding the effect of the number of initial shoots on the plantlet survival, the contrasts resulting from multiple comparisons by the Tukey test were not significant ( $p<0.05$ ), indicating that the individualized plantlet (single stem) exhibited a survival statistically similar to plantlets containing associated shoots (Table 2).

Table 1. Likelihood ratio test results among some pairs of candidate models for the survival of micropropagated bamboo plantlets at 60 days of pre-acclimatization.

\begin{tabular}{cllcc}
\hline Test & \multicolumn{1}{c}{ Model $_{1}$} & \multicolumn{1}{c}{ Model $_{2}$} & Statistical test (2LL) & P-valor \\
\hline 1 & $\mathrm{Y} \sim 1$ (without predictors) & $\mathrm{Y} \sim \mathrm{B}$ & 11.33517 & $0.003456^{*}$ \\
2 & $\mathrm{Y} \sim 1$ (without predictors) & $\mathrm{Y} \sim \mathrm{T}$ & 4.933867 & 0.084845 \\
3 & $\mathrm{Y} \sim \mathrm{B}$ & $\mathrm{Y} \sim \mathrm{B}+\mathrm{T}$ & 1.697115 & 0.428032 \\
4 & $\mathrm{Y} \sim \mathrm{B}+\mathrm{T}$ & $\mathrm{Y} \sim \mathrm{B}+\mathrm{T}+\mathrm{B} * \mathrm{~T}$ & 7.082909 & 0.131571 \\
\hline
\end{tabular}

Y: survival (yes/no); T: plantlet height class; B: number of initial shoots. * Significant at $\alpha=0.05$.

Table 2. Contrasts of multiple comparisons at $5 \%$ of significance in micropropagated Guadua aff. chacoensis plantlets, as a function of the initial number of shoots, at 60 days of pre-acclimatization.

\begin{tabular}{ccccccc}
\hline Comparison & Contrast & Inferior limit & Upper limit & Standard error & z-valor & p-valor \\
\hline CLns2-CLns1 & 1.1487 & -0.0346 & 2.3212 & 0.5098 & 2.253 & $0.0593^{\text {ns }}$ \\
CLns3-CLns1 & 1.7403 & -0.0016 & 2.4821 & 0.7504 & 2.319 & $0.0505^{\text {ns }}$ \\
CLns3-CLns2 & 0.5915 & -1.3782 & 2.5612 & 0.8485 & 0.697 & $0.7582^{\text {ns }}$ \\
\hline
\end{tabular}

${ }^{n s}$ Not significant at $\alpha=0.05$ by the Tukey test. CLns1: one shoot per plantlet/single-stem plantlet; CLns2: two shoots per plantlet; CLns3: three shoots per plantlet. 
It was verified that, after 60 days of preacclimatization, the Guadua aff. chaparensis plantlets had a survival rate of over $88 \%$. Nonetheless, a higher survival was observed in plantlets with two or three shoots, respectively $95.9 \%$ (CLns2: two shoots per plantlet) and $97.7 \%$ (CLns3: three shoots per plantlet) (Figure 2). These results demonstrate the importance of the presence of shoots on the survival and growth of micropropagated plantlets during the pre-acclimatization stage.

Determining the conditions of the micropropagated plant and of the ex vitro environment is decisive in the process of acclimatization of propagules resulting from in vitro cultivation, as a way of ensuring a high percentage of survival and adequate development, and a guarantee of success after field planting (Singh et al. 2013). Despite the morphological and physiological differences among the species, micropropagated bamboo plants exhibit

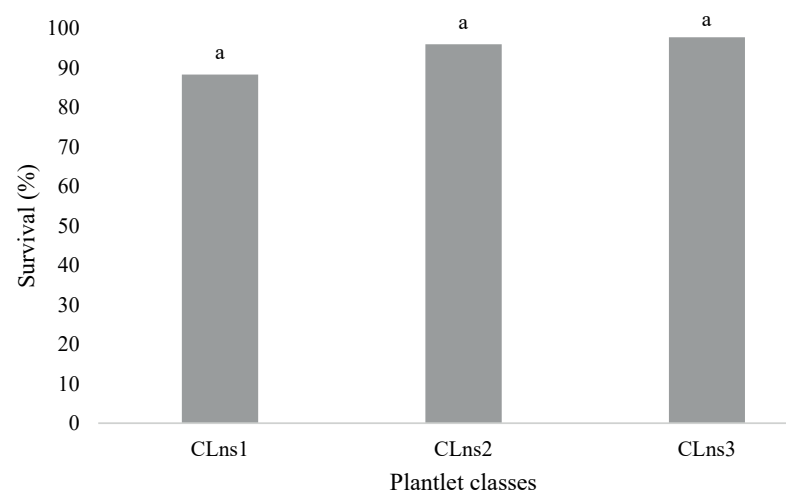

Figure 2. Survival of micropropagated Guadua aff. chaparensis plants under the effect of the number of shoots constituting the plantlet (CLns1: one shoot per plantlet/ single-stem plantlet; CLns2: two shoots per plantlet; CLns3: three shoots per plantlet), at 60 days of preacclimatization. Equal letters indicate the absence of significant differences at $5 \%$ by the Tukey test. a high survival rate to the acclimatization process, as reported by Anand et al. (2013) with Bambusa bambos ( $80 \%$ of survival), Mishra et al. (2011) with Bambusa tulda (91.0 \%), García-Ramírez et al. (2015) with Bambusa vulgaris (75\%), Gantait et al. (2018) with Bambusa balcooa (95.8\%) and Jiménez et al. (2006) with Guadua chacoensis $(85 \%)$. In the present study, survival ranged from $88.3 \%$ to $97.7 \%$, without significant differences between the classes of plant height and number of initial shoots.

The effects of treatments on the ex vitro development of the micropropagated plants showed a significant influence of the initial plant height and the number of initial shoots on the height, number of new shoots and biomass, in plantlets preacclimatized for 90 days (Table 3). After 90 days of pre-acclimatization, significant differences were observed in both the height and number of shoots and roots, as well as dry and fresh mass of the plantlets. In general, larger plantlets generated individuals with a significantly greater height.

The Tukey test comparisons show the variations of the number of shoots and roots formed according to the height and plantlet type used for pre-acclimatization. There was an increase in the emission of new shoots and roots due to the larger height and number of shoots of the pre-acclimatized plants (Table 4). The greater emission of new shoots in acclimatized plantlets may allow further multiplications by separation of sprouts, increasing the number of plantlets suitable for final planting, since the resulting plants are already adapted to the natural environment (Sharma \& Sarma 2013).

The highest number of new shoots was obtained from pre-acclimatized plants with height equal to or greater than $5.0 \mathrm{~cm}$ (CL2 and CL3) and showing 2 or 3 shoots (CLns2 and CLns3).

Table 3. Influence of height and number of initial shoots of Guadua aff. chaparensis plantlets on plant height, after 90 days of preacclimatization.

\begin{tabular}{ccccccc}
\hline \multirow{2}{*}{$\begin{array}{c}\text { Plantlet } \\
\text { height }\end{array}$} & \multicolumn{3}{c}{ Plantlet classes (number of initial shoots per plantlet) } \\
\cline { 2 - 7 } & Average $( \pm$ SE) & Groups & Average $( \pm$ SE) & Groups & Average ( \pm SE) & Groups \\
\cline { 2 - 7 } & $10.9 \pm 4.6$ & Aa* & $17.7 \pm 5.1$ & ABb & $14.9 \pm 4.4$ & $\mathrm{Bab}$ \\
CL1 & $11.9 \pm 3.0$ & Aa & $14.8 \pm 4.6$ & ABa & $17.3 \pm 4.5$ & $\mathrm{Ba}$ \\
CL2 & $14.1 \pm 4.2$ & Aa & $19.1 \pm 4.7$ & $\mathrm{Bb}$ & $18.8 \pm 3.6$ & $\mathrm{Ba}$ \\
CL3 & &
\end{tabular}

* Uppercase letters represent the comparison between the plantlets height, defining the plantlet classes according to the number of shoots, while lowercase letters represent the comparison between the plantlets, in relation to the number of initial shoots, according to height $(\mathrm{p}<0.05)$. Contrasts were performed according to the Tukey test, at $5 \%$ of significance. P-value adjusted by the single-step method. CL1: 2.5-5.0 cm; CL2: 5.1-10.0 cm; CL3: 10.1-15 cm; CLns1: one shoot per plantlet/single-stem plantlet; CLns2: two shoots per plantlet; CLns3: three shoots per plantlet; SE: standard error. 
Table 4. Influence of height and number of shoots of initial Guadua aff. chaparensis plantlets on the number of shoots and roots, at 90 days of pre-acclimatization.

\begin{tabular}{|c|c|c|c|c|c|c|}
\hline \multirow{3}{*}{$\begin{array}{c}\text { Plantlet } \\
\text { height }\end{array}$} & \multicolumn{6}{|c|}{ Plantlet classes (number of initial shoots per plantlet) } \\
\hline & \multicolumn{2}{|c|}{ CLns1 } & \multicolumn{2}{|c|}{ CLns2 } & \multicolumn{2}{|c|}{ CLns3 } \\
\hline & Average $( \pm$ SE) & Groups & Average $( \pm \mathrm{SE})$ & Groups & Average $( \pm \mathrm{SE})$ & Groups \\
\hline \multicolumn{7}{|c|}{ Number of shoots per plantlet } \\
\hline CL1 & $2.5 \pm 1.0$ & $\mathrm{Aa}^{*}$ & $3.40 \pm 1.0$ & $\mathrm{Aa}$ & $3.80 \pm 1.5$ & Aa \\
\hline CL2 & $3.2 \pm 0.9$ & $\mathrm{Aa}$ & $4.60 \pm 1.8$ & $\mathrm{Ba}$ & $5.10 \pm 1.4$ & $\mathrm{Ba}$ \\
\hline CL3 & $3.2 \pm 1.3$ & $\mathrm{Aa}$ & $4.40 \pm 1.3$ & $\mathrm{ABa}$ & $5.50 \pm 2.1$ & $\mathrm{Ba}$ \\
\hline \multicolumn{7}{|c|}{ Number of roots per plantlet } \\
\hline CL1 & $6.0 \pm 3.2$ & Aa & $8.60 \pm 2.7$ & $A a b$ & $10.00 \pm 3.1$ & $\mathrm{Ab}$ \\
\hline CL2 & $7.5 \pm 2.1$ & $\mathrm{ABa}$ & $9.95 \pm 4.1$ & $\mathrm{ABab}$ & $12.65 \pm 2.3$ & $\mathrm{Ab}$ \\
\hline CL3 & $8.8 \pm 3.1$ & $\mathrm{Ba}$ & $12.70 \pm 2.1$ & $\mathrm{Ba}$ & $12.80 \pm 4.6$ & $\mathrm{Aa}$ \\
\hline
\end{tabular}

By evaluating the influence of plant height on micropropagated Bambusa vulgaris, García-Ramírez et al. (2015) found that $4.0-\mathrm{cm}$ plantlets had a higher net assimilation rate, leaf area, individual growth and root and leaf emission in pre-acclimatization, if compared to those with a height of $3.0 \mathrm{~cm}$.

For the number of roots, the best results were obtained in the combination of individual plantlets (single stem) and height starting at $5.0 \mathrm{~cm}$ (CL2), and in the treatment with 2 shoots (CLns2), with plantlets measuring 5.0-10.0 cm (CL2), which differed significantly from the other treatments (Table 4). The higher number of roots in the pre-acclimatization phase is an important factor in acclimatization, because it ensures better conditions for plant survival and growth, since the roots set the plant onto the substrate and absorb water and mineral nutrients (Oliveira et al. 2008).

The production and allocation of biomass in bamboo is influenced by factors such as the amount of available water in the substrate or the soil, intensity and quality of light, and quantity and balance of the nutrients present in the substrate (Oliveira et al. 2008). Additionally, it is imperative that micropropagated plants exhibit adequate structural and physiological characteristics that guarantee a minimum of stress when submitted to the ex vitro environment, with a rapid adaptation, high survival and development in the field (Luis et al. 2010).

Thus, the knowledge of the gain in biomass, due to the organogenic process, both for shoots and roots, may be decisive in predicting the survival rate of large-scale plants, since structures with a higher biomass can enable plants to more easily overcome the environmental differences and other types of stress resulting from acclimatization. The unequal formation of shoots and roots is recurrent in plants grown in vitro, and may be attributed to the species or factors such as explant origin, cultivation system (liquid medium, semi-solid medium, bioreactors) and unequal physiological activity of meristematic cells, or be caused by somaclonal variation (Darwesh 2015, García-Ramírez et al. 2015, Gomes et al. 2015).

In this study, higher values for shoot fresh biomass were concentrated in the treatments composed of plantlets with a greater initial height (CL2 and CL3; 5.0-15.0 cm) and presence of initial shoots (CLns2 or CLns3, two or three aggregate shoots). Greater root fresh and dry biomass were obtained when plantlets with two or three initial shoots were used $(p<0.05)$, regardless of the plant height. Similar results were observed in larger plantlets (CL2 and CL3) with two to three associated shoots (CLns2 and CLns3) (Table 5). These results demonstrate the importance of plant height standardization and support management practices in the pre-acclimatization and/or acclimatization stages in micropropagated bamboo.

The results obtained in this study allows to affirm that, at 90 days of pre-acclimatization, the survival of micropropagated Guadua aff. chaparensis plantlets is not significantly influenced by height (3.0$15.0 \mathrm{~cm}$ ) and presence of initial shoots of the plantlet used. According to the present research, plantlets with a height of more than $5.0 \mathrm{~cm}$ and 2 or 3 associated shoots are more suitable for greater emission of new shoots and roots, as well as accumulation of fresh and dry biomass. 
Table 5. Influence of height and number of initial shoots of Guadua aff. chaparensis plantlets on fresh and dry mass, at 90 days of pre-acclimatization.

\begin{tabular}{|c|c|c|c|c|c|c|}
\hline \multirow{3}{*}{$\begin{array}{l}\text { Plantlet } \\
\text { height }\end{array}$} & \multicolumn{6}{|c|}{ Plantlet classes (number of initial shoots per plantlet) } \\
\hline & \multicolumn{2}{|l|}{ CLns1 } & \multicolumn{2}{|c|}{ CLns2 } & \multicolumn{2}{|c|}{ CLns3 } \\
\hline & Average $( \pm$ SE) & Groups & Average $( \pm$ SE $)$ & Groups & Average $( \pm$ SE) & Groups \\
\hline \multicolumn{7}{|c|}{ Shoot fresh biomass $(\mathrm{g})$} \\
\hline CL1 & $1.16 \pm 1.76$ & $\mathrm{Aa}^{*}$ & $2.50 \pm 1.56$ & $\mathrm{Aa}$ & $2.61 \pm 1.50$ & $\mathrm{Aa}$ \\
\hline CL2 & $1.55 \pm 1.00$ & $\mathrm{Aa}$ & $2.95 \pm 2.08$ & $\mathrm{ABa}$ & $3.88 \pm 1.37$ & $\mathrm{Bab}$ \\
\hline CL3 & $2.44 \pm 1.45$ & $\mathrm{Aa}$ & $3.78 \pm 1.32$ & $\mathrm{ABa}$ & $4.69 \pm 1.55$ & $\mathrm{Bb}$ \\
\hline \multicolumn{7}{|c|}{ Root fresh biomass $(\mathrm{g})$} \\
\hline CL1 & $1.30 \pm 1.48$ & $\mathrm{Aa}$ & $4.02 \pm 2.44$ & $\mathrm{Ab}$ & $3.21 \pm 1.65$ & $\mathrm{Ab}$ \\
\hline CL2 & $1.97 \pm 1.09$ & $\mathrm{ABa}$ & $3.88 \pm 2.70$ & $\mathrm{Ab}$ & $5.62 \pm 2.02$ & $\mathrm{Ab}$ \\
\hline CL3 & $2.83 \pm 1.63$ & $\mathrm{Ba}$ & $5.01 \pm 1.61$ & $\mathrm{Aab}$ & $6.16 \pm 2.34$ & $\mathrm{Ab}$ \\
\hline \multicolumn{7}{|c|}{ Shoot dry biomass (g) } \\
\hline CL1 & $0.35 \pm 0.46$ & $\mathrm{Aa}$ & $0.83 \pm 0.56$ & $\mathrm{Ab}$ & $0.65 \pm 0.32$ & Aab \\
\hline CL2 & $0.49 \pm 0.29$ & $\mathrm{Aa}$ & $0.99 \pm 0.64$ & $\mathrm{Aab}$ & $1.32 \pm 0.51$ & $\mathrm{Ab}$ \\
\hline CL3 & $0.68 \pm 0.38$ & $\mathrm{Aa}$ & $1.01 \pm 0.37$ & $\mathrm{Aab}$ & $1.56 \pm 0.57$ & $\mathrm{Ab}$ \\
\hline \multicolumn{7}{|c|}{ Root dry biomass (g) } \\
\hline CL1 & $0.13 \pm 0.16$ & $\mathrm{Aa}$ & $0.23 \pm 0.14$ & $\mathrm{Aa}$ & $0.27 \pm 0.15$ & $\mathrm{Aa}$ \\
\hline CL2 & $0.18 \pm 0.11$ & $\mathrm{Aa}$ & $0.35 \pm 0.24$ & $\mathrm{ABb}$ & $0.43 \pm 0.15$ & $\mathrm{ABb}$ \\
\hline CL3 & $0.26 \pm 0.15$ & $\mathrm{Aa}$ & $0.43 \pm 0.15$ & $\mathrm{Bb}$ & $0.56 \pm 0.20$ & $\mathrm{Bb}$ \\
\hline
\end{tabular}

* Uppercase letters represent the comparison between the plantlets height, defining the plantlets classes according to the number of shoots, while lowercase letters represent the comparison between plantlets, in relation to the number of shoots, according to height. Contrasts were performed according to the Tukey test at $5 \%$ of significance. P-value adjusted by the single-step method. CL1: 2.5-5.0 cm; CL2: 5.1-10.0 cm; CL3: 10.1-15 cm; CLns1: one shoot per plantlet/single-stem plantlet; CLns2: two shoots per plantlet; CLns3: three shoots per plantlet; SE: standard error.

\section{CONCLUSIONS}

1. The plantlet height and number of shoots aggregated to plantlets originating from micropropagation do not influence the survival rates of Guadua aff. chaparensis during pre-acclimatization;

2. Micropropagated Guadua aff. chaparensis plantlets with an average height greater than $5.0 \mathrm{~cm}$ and presence of two or three aggregate shoots have a greater development at 90 days of pre-acclimatization.

\section{ACKNOWLEDGMENTS}

The authors are grateful to the Conselho Nacional de Desenvolvimento Científico e Tecnológico (CNPq), Coordenação de Aperfeiçoamento de Pessoal de Nível Superior (Capes), Fundação de Amparo à Pesquisa do Estado do Acre (FAPAC - CVT bambu) and Centro de Pesquisa e Aplicação de Bambu e Fibras Naturais (CPAB) for the fellowship, research grants and financial support.

\section{REFERENCES}

ANAND, M.; BRAR, J.; SOOD, A. In vitro propagation of an edible bamboo Bambusa bambos and assessment of clonal fidelity through molecular markers. Journal of Medical and Bioengineering, v. 2, n. 4, p. 257-251, 2013.

BARTLETT, M. S. Properties of sufficiency and statistical tests. Proceedings of the Royal Society of London: Series A, Mathematical and Physical Sciences, v. 160, n. 901, p. 268-282, 1937.

BURNHAM, K. P.; ANDERSON, D. R. Model selection and multimodel inference: a practical information-theoretic approach. 2. ed. New York: Springer, 2002.

DARWESH, R. S. S. Morphology, physiology and anatomy in vitro affected acclimatization ex vitro date palm plantlets: a review. International Journal of Chemical, Environmental \& Biological Sciences, v. 3, n. 2, p. 183190, 2015.

DAS, M. et al. Bamboo taxonomy and diversity in the era of molecular markers. In: KADER, J.; DELSENY, M. (Eds.). Advances in botanical research. Cambridge: Academic Press, 2008. p. 225-268.

GANTAIT, S.; PRAMANIK, B. R.; BANERJEE, M. Optimization of planting materials for large scale plantation of Bambusa balcooa Roxb.: influence of propagation methods. Journal of the Saudi Society of Agricultural Sciences, v. 17, n. 1, p. 79-87, 2018.

GARCÍA-RAMÍREZ, Y. et al. Effect of morphological and physiological development on the acclimatization of in vitro plants of Bambusa vulgaris Schrad ex Wendl 
in liquid culture medium. Open Access Library Journal, v. 2, e1787, 2015.

GILLIS, K. et al. Somatic embryogenesis from mature Bambusa balcooa Roxburgh as basis for mass production of elite forestry bamboos. Plant Cell, Tissue and Organ Culture, v. 91, n. 1, p. 115-123, 2007.

GOMES, H. T.; BARTOS, P. M. C.; SCHERWINSKIPEREIRA, J. E. Optimizing rooting and survival of oil palm (Elaeis guineensis) plantlets derived from somatic embryos. In Vitro Cellular \& Developmental Biology Plant, v. 51, n. 1, p. 111-117, 2015.

GRECO, T. M.; PINTO, M. M.; TOMBOLATO, A. F. C. Diversity of bamboo in Brazil. Journal of Tropical and Subtropical Botany, v. 23, n. 1, p. 1-16, 2011.

JIMÉNEZ, V. M. et al. In vitro propagation of neotropical giant bamboo, Guadua angustifolia Kunth, through axilary shoot proliferation. Plant Cell, Tissue and Organ Culture, v. 86, n. 3, p. 389-395, 2006.

KLEINHENZ, V.; MIDMORE, D. J. Aspects of bamboo agronomy. Advances in Agronomy, v. 74, n. 1, p. 99-149, 2001.

LIN, X. C. et al. Understanding bamboo flowering based on large scale analysis of expressed sequence tags. Genetics and Molecular Research, v. 9, n. 2, p. 10851093, 2010.

LUIS, Z. G.; GOMES-BEZERRA, K. M.; SCHERWINSKIPEREIRA, J. E. Adaptability and leaf anatomical features in oil palm seedlings produced by embryo rescue and pregerminated seeds. Brazilian Journal of Plant Physiology, v. 22, n. 3, p. 209-215, 2010.

MISHRA, Y.; PATEL, P.; ANSARI, S. A. Acclimatization and macroproliferation of micropropagated plants of Bambusa tulda Roxb. Asian Journal of Biological Sciences, v. 2, n. 3, p. 408-411, 2011.
MURASHIGE, T.; SKOOG, F. A revised medium for rapid growth and bio assay with tobacco tissue culture. Physiology Plantarum, v. 15, n. 3, p. 473-497, 1962.

NOGUEIRA, J. S. et al. Micropropagação de bambu em larga-escala: princípios, estratégias e desafios. In: DRUMOND, P. M.; WIDEMAN, G. (Orgs). Bambus no Brasil: da biologia à tecnologia. Rio de Janeiro: $\mathrm{ICH}$, 2017. p. 103-129.

OLIVEIRA, D. A. et al. Alocação de biomassa em plantas de bambu em resposta a adubação mineral. Scientia Agraria, v. 9, n. 2, p. 139-146, 2008.

RAMANAYAKE, S. M. S. D. Flowering in bamboo: an enigma! Ceylon Journal of Science, v. 35, n. 2, p. 95-105, 2006.

SHARMA, P.; SARMA, K. P. In vitro propagation of Bambusa balcooa for a better environment. Journal of Environmental Research and Development, v. 7, n. 3, p. 1216-1223, 2013.

SINGH, S. R. et al. Limitations, progress and prospects of application of biotechnological tools in improvement of bamboo - a plant with extraordinary qualities. Physiology Molecular Biology of Plants, v. 19, n. 1, p. 21-41, 2013.

SOUSA, J. R. L. Propagação vegetativa em viveiro e variabilidade genética de multiespécies de bambu ex situ. 2018. 112 f. Tese (Doutorado em Ciências Florestais) Universidade de Brasília, Brasília, DF, 2018.

VAN HUYLENBROECK, J. M.; DEBERGH, P. C. Impact of sugar concentration in vitro on photosynthesis and carbon metabolism during ex vitro acclimatization of Spathiphyllum plantlets. Physiologia Plantarum, v. 96, n. 2, p. 298-304, 1996.

ZHAO, X. Y. et al. Investigating the microRNAomes of two developmental phases of Dendrocalamus latiflorus (Poaceae: Bambusoideae) inflorescences. Plant Molecular Biology Reporter, v. 33, n. 4, p. 1141-1155, 2015. 